\title{
The Author is Dead, Long Live the Author! Postmodern Metanarrative and the Performance of the Author Function
}

\author{
Arnab Dasgupta \\ PhD Scholar (JRF), Presidency University, banjogray@gmail.com
}

\begin{abstract}
This research paper critically examines the meta-narrative text The Master of Petersburg, a novel by Nobel laureate J.M. Coetzee, which has the figure of the author at the centre of its narrative structure. In his fictions, Coetzee is not shy of dislodging the what Roland Barthes calls 'reality effect' in order to critically assert the role of the authorial figure; this is also to be seen in the novel Slow Man where Coetzee ruptures the realist texture of the narrative by introducing the figure of Elizabeth Costello who enters the text, as well as the life of Paul Rayment an amputee, as the author figure who is responsible for her creation i.e. Paul Rayment himself. At the same time Coetzee in order to explore the issues of writing at its ethical dimension, transforms some realist tropes at his disposal. For instance, in Elizabeth Costello, Coetzee with a brilliant manoeuvre plays on the trope of epistolary novels and presents the novel in a form of series of lectures delivered by the Elizabeth Costello, an Australian author of international fame. But in a brilliant ironical move Coetzee through the performance of the authorial voice breaks the realist structure of Novel. The paper will however, primarily focus on the novel The Master of Petersburg (1994), which is a meta-narrative in which Coetzee actively interrogates into the ethics of writing as in this novel he places the fictively reimagined figure of Dostoevsky in Petersburg in the late 1868, after the murder of his step-son Pavel. In this novel like his earlier novel Foe(1986), Coetzee examines the process of artistic creation and ethics involved in the event of writing, as Coetzee in his novel evokes a mix of historical factors and fictive characteristics which inspired and featured in Dostoevsky's novel The Devils. Through a close examination of the interstitial spaces between the two novels this paper explores the figure of the author and its performance in the postmodern fiction. The author as figure has caused much debate in the postmodern fiction and narrative theory. Post Roland Barthes's declaration 'author is dead' many deconstructionist and narrative theory have debated the relevance of author figure in fiction, and the meta-narrative and self-referential nature of postmodern literature makes these debates even more potent. This paper seeks to explore the debate concerning the author figure from Bakhtin, Barthes, Bennet and Foucault and try to understand the implications which the author figure has in a postmodern text through a close examination of Coetzee's The Master of Petersburg.
\end{abstract}

\section{Keywords}

Author figure, Authorfunction, Metafiction, Narrative theory, Performance theory, Postmodernity.

This Open Access article is published under a Creative Commons Attribution Non-Commercial 4.0 International License (http://creativecommons.org/licenses/by-nc/4.0/), which permits non-commercial re-use, distribution, and reproduction in any medium, provided the original work is properly cited. For citation use the DOI. For commercial re-use, please contact editor@rupkatha.com. 
"The progress of an artist is a continual self-sacrifice, a continual extinction of personality."

-Tradition and Individual Talent. T. S. Eliot

"I write perversions of the truth. I choose the crooked road and take children into dark places. I follow the dance of the pen"

The Master of Petersburg. J. M. Coetzee

Postmodernist narratives with their penchant for self-referential structures and metalingual wordplay, continuously wrestle with the crisis posed by the uncanny, undecidable figure of the author.Despite its alleged aversion towards essentialism and humanism the postmodern literature seems fixated or even fascinated by the "author effects" and "author-figures". In his famous essay "The Death of the Author" Roland Barthes observes "Writing is that neutral, composite, oblique space where our subject slips away, the negative where all identity is lost, starting with the very identity of the body writing" (p.185). This constitutes the central argument in Barthes's famous pronouncement of the "death of the author". This death of the author and in extension the death of the subject is synecdochally projected as a defining feature of the postmodern project. However, David Attwell makes us aware that Barthes's idea of dismantling the author as a cultural institution should not be confused with what he had to say about the psychic and existential demands of authorship itself. Barthes himself acknowledges in "Authors and Writers" "Not that the author is a pure essence: he acts, but his action is immanent in its own instrument: language". For Barthes the author is "a man who radically absorbs the worlds why in a how to write." Author is then a uniquely form giving energy functional through the language he uses, within a particular cultural discourse. However, this figure of the author in realist texts usually stays confined to the boundaries of the literary texts and it is very strange and uncanny when the figure of the author nominally invades the central textual territories. M. M. Bakhtin writes in his early essay 'Author and Hero in Aesthetic Activity" "The author must be situated on the boundary of the world he is bringing into being as the active creator of this world', Bakhtin declares, 'for his intrusion into that world destroys its aesthetic stability' (1990, p.191). However, it is this very destruction of the aesthetic unity and stability of the text through the uncanny presence of the author that is sought by the Postmodern novels, as a performative device to highlight the literariness of literature. But the presence of this figure of the "author" must not be conflated with the historical and cultural figure of the author. As Lyotard makes it clear in The Postmodern Condition, that postmodernity is essentially characterised by a disruption where "the aesthetic object is detached from the temporality of original creation and repetition so as to no longer be a commodity circulating between artist and critic." (Reading, p.42) This detachment of the "aesthetic object" from its source of creation frees the aesthetic object or the text from the tyranny of historical author. Thus, what haunts the text in the Postmodern novel then is not the historical figure of the author, but what Foucault calls "author-function" which "does not develop spontaneously as the attribution of a discourse to an author. It is rather, the result of complex operations which constructs a certain rational being that we call "author" (p. 197).

Lyotard also makes it clear in The Postmodern Condition that postmodernity is essentially characterised by a disruption where "the aesthetic object is detached from the temporality of original creation and repetition so as to no longer be a commodity circulating between artist and critic." (1991, p.42) This detachment of the "aesthetic object" from its source of creation frees the aesthetic object or the text from the tyranny of historical author. This allows for a possibility of a 
self-referential engagement of the author with narrative process. It follows that the author no longer has any responsibility towards any particular narrative mode or even towards the literariness of the text. It is a prospect which allows for the introduction of 'meta' level of narrative in fiction, as the author can now playfully bring his own subjective voice in reference, making the narrative metafictional. Paul Cobley describes "Metafiction" as:

Written fiction which is characterised by varieties of the rupturing effect. It is usually associated with postmodernism because it involves one narrative mode being "ruptured", "undermined" or "invalidated" by another, as when a narrative mode as discourse may throw into question a passage of histoire. (Cobley, 2001, p. 235)

Patricia Waugh observes metafiction is "a term given to fictional writing which self-consciously and systematically draws attention to its status as an artefact in order to pose questions about the relationship between fiction and reality." (Waugh 1984: 2) The term metafiction which originated in the writings of William $\mathrm{H}$. Gass, reflects the way in which the humans construct, mediate and experience their reality. By using the analogy of book as the world, metafiction helps the reader to cognitively engage with the human subjectivity as a performative act.

J. M. Coetzee, is central to any discussion of postmodern metafiction. He probes continuously into the figure of the "author", and engages with issues of nature of writing and the relationship and responsibilities the writer shares and owes to writing, particularly within a metafictional structure. His novels - Foe, The Master of Petersburg, Elizabeth Costello and Slow Man - are metafictions which extensively deal with the performance of the "author figure", nature of writing and the relationship between the writer and his work, where the writer invents, and is simultaneously (re)invented by his creation. Taking up this theme of (re)invention of the author by his creation, Coetzee speaks through the fictive figure of Robinson Crusoe in his Nobel Lecture "He and his Man", where Crusoe an old man from Bristol writes Defoe into existence. "In the evening by candlelight he will take out his papers and sharpen his quills and write a page or two of his man ..." (Coetzee 2003 Noble lecture) There is a need to explore this artistic performativity and relationship between the author and his "man". In one of his early novels The Master of Petersburg, Coetzee explores the issues of authorship and responsibility and dares to place the Master (Dostoevsky) himself at the centre of the text, deriving inspiration from Dostoevsky's poetics and from the historical figure of Dostoevsky himself. Coetzee in this text, as he does in Foe, examines and imagines from margin the disruptive process of creation of one of the European classics, Dostoevsky's The Devils.

The performative of the author figure in The Master of Petersburg is initiated with the return of the fictionalised Dostoevsky to Petersburg, in the Russian autumn of 1869. Dostoevsky, (both fictional and historical) at this time was staying in Dresden to escape his creditors, and the cause of his journey is to collect the personal effects of his stepson, Pavel, who is found dead under mysterious circumstances. However, Pavel's personal papers include a highly seditious terrorist hit list which is in the custody of the tsarist police, in his effort to get back his stepson's personal effects from the police Dostoevsky gradually gets implicated into an antagonistic relationship with the authority. He also comes in contact with Nechaev, the historical as well as the fictional nihilist and anti-tsarist, who is suspected of killing Pavel. Dostoevsky moves into Pavel's former lodging and initiates a passionate, and in some respect a therapeutic relationship with the landlady. He is 
also developing a perverted desire for young daughter Matryona. These incidents, circumstances, desires and emotion, Coetzee goes on to suggest, form the intrinsic core of Dostoevsky's writing, specifically the novel The Devils which Dostoevsky was writing at this point of his life. More particularly, as Coetzee suggests Dostoevsky's un-acted desires are the source of "moral carnality" of the character of Stavrogin in his novel The Devils. In an act of metacommentary, Coetzee names the last chapter of his novel on Dostoevsky's anti-hero 'Stavrogin'. Thus, following Bakhtin's dicta, the author figure of Dostoevsky as presented by Coetzee, does not renounce his own consciousness but broadens and rearranges it in the consciousness of the hero/ anti-hero.

"Literary fiction" argues Derrek Attridge in The Singularity of Literature "involves the 'performance' of fictionality, occupying as the experience of an event or a series of events whereby the characters and occurrences apparently being referred to are in fact, and without this fact being disguised, brought into being by the language." (Attridge, 2004, p.96) This "performance of fictionality" is the constitutive force in Coetzee's transfiguration of fictionalised Dostoevsky. Readers are made aware of several departures which Coetzee made from the historical biography of Dostoevsky; the real Dostoevsky was survived by his son for instance. Commenting on the discrepancies between the biography of Dostoevsky and Coetzee's production of Dostoevsky's life W. J Leatherbarrow suggests that it is an interesting, though historically unreliable, fictional account of the period in Dostoevsky's life when he was working on The Devils. But Coetzee does rely on historical figures and events to some extent in his conceptualization of the plot of The Master of Petersburg. Most notable historical influence for Coetzee is the figure of Nechaev, the nihilist and anarchist, who was involved in the murder of the fellow student Ivanov, an incident which is also the source of Dostoevsky's The Devils. Dominic suggests that, "At the heart of the novel is the confrontation between Nechaev and Coetzee's 'Dostoevsky', and this confrontation links the novel's central ideas pertaining to questions of 'fathering', authorship and morality" (Head, 2009, p.73).

The author narrator of The Master of Petersburg, the author-function of Dostoevsky, is ontologically troubled by the same tormenting questions and dilemmas which are faced by young John of Coetzee's quasi-memoir Youth. Both of them are troubled by the problem of striking a balance between the demands of the life of a writer and those of self-censorship. The question which bothers them both is to what extent a complete self expression is possible and desirable without infringing on the bounds of the ethical. For young John in Youth, "The question of what should be permitted to go into his diary and what kept forever shrouded goes to the heart of all his writing." He wonders "If he is to censor himself from expressing ignoble emotions...how will those emotions ever be transfigured and turned into poetry?" (Coetzee, 2002, p.10) In comparison Dostoevsky seems a bit more assured about the relationship between the private life of the author and the work of fiction he creates. Thus, when Dostoevsky is asked by the police investigator Maximov "Is story a private matter, would you say?" (Coetzee, 1994, p. 39). The master replies "A private matter, an utterly private matter, private to the writer, till it is given to the world" (Coetzee, 1994, p. 40).

But the moment the "private matter" is "given to the world" (Coetzee 1994, p.40), it becomes an event of betrayal. Dostoevsky betrays Pavel and perverts the act of mourning for the death of his stepson by making it subsidiary to his business of writing. This artistic perversion produces an entirely unfavourable portrait of Pavel and is reflected in his characterization of Stavrogin which 
he leaves behind for Matroyona to read, which again is a betrayal of trust of the young girl. These acts of betrayal, which the author figure engages in continuously, throughout the text stems from the authors absolute responsibility towards artistic (re)creation. In Gift Of Death Derrida describes absolute responsibility as an absolute singularity. It "is not a responsibility, at least it is not general responsibility or responsibility in general," so "it must therefore be irresponsible in order to be absolutely responsible" (Derrida, 2007, p. 61). For an author, to be absolutely responsible to his work, he/she has to be irresponsible to all others (ethics). This absolute responsibility of the author towards act of writing is well delineated by the author figure of Dostoevsky in the chapter Stavroginwhere he describes the act of writing as an act of betrayal "betrayal of love first of all, and then of Pavel and the mother and child and everyone to be turned to another use, to be gripped to him and fall with him." (Coetzee, 1994, p.235) The author must betray continuously in order to create.

Coetzee's Dostoevsky in the final cosmic vision of his, in The Master of Petersburg, as a creative writer, confronts God. After writing the pages on the perversion of Stavrogin which in reality is a perverted trans-creation of Pavel's character, Dostoevsky realizes that he pays a great price for his writing. Dostoevsky visualizes Matryona echoing the same sarcastic comment about his writing as his dead son Pavel, "They pay him lots of money for writing books" (Coetzee, 1994, p. 250). But Dostoevsky laments that both Pavel and Matryona fail to understand that "he had to give up his soul in return." (Coetzee, 1994, p. 250). This giving up of soul implies that writing is a performative act where the writer must host the other in order to write. Stephen Watson very aptly writes about The Master of Petersburg.

To write one has to transgress, to be divided, even double. But to be double is to open oneself to the possibility of being overtaken by another voice. This voice may be anything but benign; it may even be that of the Devil himself. (Watson, 1994, p. 56).

This act of doubling is also performed by Coetzee who opens up to Dostoevsky's voice as well his writing , particularly his novel ,The Devils.The said novel is important for Coetzee it is in this text, Dostoevsky takes his "last steps in the exploration of the limits of secular confession" (Coetzee, 1992, p.287). In The Master of Petersburg, his strategy for confronting the limits of secular confession is an intertextual engagement with The Devils, and more particularly, with the suppressed 'At Tikhon's' chapter, in which Stavrogin gives the monk Tikhon his written confession. Stavrogin's crimes include the apparent seduction of his landlady's fourteen-year-old daughter, and his failure to intervene when he suspects the despairing girl is about to commit suicide. In 'Confession and Double Thoughts: Tolstoy, Rousseau, Dostoevsky', Coetzee points out that there is a mutual interrogation in 'At Tikhon's': Tikhon is probing Stavrogin's motivation whilst Stavrogin is evaluating Tikhon's credentials as confessor. Coetzee's analysis of The Devils is quite similar to Bakhtins's reading of the novel in Problems of Dostoevsky's Poetics. Tikhon's function in the novel is to open up the circular monologism of Stavrogin's confession thereby it subverts the author's control and introduces a dialogism in the novel. The same question of authority in The Master of Petersburg is interrogated by Coetzee through a meta-commentary on Dostoevsky's novel. Stavrogin's crime against Matryona, his landlady's daughter, in The Devils is projected onto 'Dostoevsky' when he visits Petersburg in Coetzee's novel, and becomes fascinated with the landlady's daughter also named Matryona. The author figure is therefore implicated in the crime 
that the real Dostoevsky will project onto Stavrogin when he composes The Devils. As Dominic Head points out "The Master of Petersburg insists on the compromised, the divided authorial self, it is an extended form of excoriatingly honest confession in itself."(Head, 2009, p. 76)

In The Master of Petersburg issues like function of words, authorship, ethics of reading and writing are delineated in the debates between Nechaev and Dostoevsky. While 'Dostoevsky' places emphasis on the responsibility taken on by the author of ideas, Nechaev promotes a heady freedom in which there is no necessary connection between speech and thought, he says : 'I can think one thing at one minute and another thing at another and it won't matter a pin as long as I act' (Coetzee, 1994, p. 200). But in a rather interesting and subversive move, this ethical responsibility of an author towards an idea is also challenged by Coetzee's fictive Dostoevsky who professed it. Coetzee suggests in the novel that Dostoevsky developed his fiction The Devils from the diary entries of his step-son Pavel, thus negating the idea of a responsible "Author-God".

This is quite akin to what Roland Barthes writes in "The Death of The Author", "text is not a line of words releasing a single 'theological' meaning (the message of the Author God) but a multi-dimensional space in which a variety of writings, none of them original, blend and clash" (Barthes, 1968, p. 188). According to Barthes "The reader is the space on which all the quotations that make up a writing are inscribed without any of them being lost"(Barthes, 1968, p. 189) and Coetzee illustrates this through the very title of the novel The Master of Petersburg, where Coetzee seems to mock the author figure of Dostoevsky as "the master", as burdened by his subjectivity, historical materiality, curtailed by censorship and personal mourning, ,- the author figure of Dostoevsky in The Master of Petersburg is a anything but "the master". The figure of Dostoevsky as depicted in Coetzee's novel lacks the authority over his own creative fiction.

In The Master of Petersburg, Coetzee clearly suggest a very close resemblance between the fictive Dostoevsky and the historical Dostoevsky. His portrayal of Dostoevsky's is way more historically influenced than his depiction of Daniel Defoe who is clearly the historical shadow lurking behind the character Foe, in the novel with same name. Interestingly Coetzee himself provide us with a detailed historical understanding of the Russian literary giant's most crucial period in his literary career between 1865 and 1871. In a review of Joseph Frank's biography of Dostoevsky published in Stranger Shores Coetzee writes how Dostoevsky's ideological stance and his personal life had a bearing upon his literary output. Commenting particularly on the genesis of The Devils, Coetzee identifies the problem of censorship as one of the major concerns which Dostoevsky faced during his writing of the novel and how this moulds the act of reading the novel:

The Devils presents particularly intransigent problems for the reader.... In the manuscript presented by Dostoevsky to the Russian Messenger, the journal in which The Devils was being serialised, there is a chapter which Stavorgin tells a priest how he seduced a young girl, then refrained from intervening while she killed herself. This chapter was rejected by Katkov, editor of the journal on moral grounds. Despite numerous rewrites, in which Dostoevsky toned down the chapter as far as he conscientiously could, Katkov, in other respects a tolerant and sympathetic man refused to relent. (Coetzee, 2002, p.143-144)

This act of self-censorship by the historical Dostoevsky becomes in Coetzee's novel, the intertextual metafictional commentary on the act of self-censorship by an author. Coetzee is well aware of the possibility of self-censorship that haunts any act of writing. He writes in Doubling 
the Point "What is a writer's freedom?... The most obvious threat is official censorship. But a 'more insidious' threat comes from the writer's 'very awareness of what is expected of him, conformity to an orthodoxy of opposition'"(Coetzee, 1992,p.382) In his essay "Metacommentary" Fredrick Jameson observes "every commentary must be at the same time a metacommentary"(Jameson, 1971, p. 10) Metacommentary takes into account both the latent and manifest workings within a text and hence it help us to answer the fundamental question "Why does the work require interpretation in the first place? by posing it forthrightly from the outset, by implying the presence of some type of Censor through which the message must slip past" (1971, p. 15)

Jameson's idea of metacommentary becomes a very potent tool, augmenting the act of reading in a text like Master of Petersburg which portrays the author in the process of self-censoring. As reader of such texts it becomes essential to interpret not just the epistemic lacunas which the author creates within the texts but to engage with the very conditions which produce such gaps. The novel Master of Petersburg depicts the awaiting of the creative impulse of The Devils, by Dostoevsky. It is this inter-textuality of Coetzee's novel which gives reader, access to both the selfcensoring authors. Laurent Jenny writes in this context "What is characteristic of intertextuality, is that it introduces a new way of reading which destroys the linearity of the text." (Jenny, 1982, p. 44) In reading The Master of Petersburg and in engaging with the fictive author figure of Dostoevsky, a constant return is made to The Devil, which is present in the text as a trace. Since in an intertextual narrative the author is able to transfuse the discourse with a multivalent parole, denser than everyday monologic discourse, Coetzee is enabled in an act of evasion and neglect of the censor and situates the reader of The Master of Petersburg as this censor-figure or critic who must fill in the gaps of the "missing" text.

In a metafiction the writer always anticipates the arrival of the reader as the new arrivant to the textual space. Coetzee's Dostoevsky portrays the dilemma of the author who waits for the arrivant reader. The Master of Petersburg can really be read as a novel of waiting. We find that in the novel the author figure Dostoevsky keeps on prolonging his stay in Petersburg, despite the risks involved in such a decision. What is Dostoevsky waiting for? The novel suggests that he prolonged his stayed in Petersburg to mourning the death of his step son Pavel. But he could have done the same on his return to Drisden too, where he was staying in exile. A possible answer to this dilemma of waiting is provided by Derrida through the idea of arrivant developed in Aporias. Derrida writes:

The new arrivant: this word can, indeed, mean the neutrality of that which arrives, but also the singularity of who arrives, he or she who comes, coming to be where he or she wasn't expected, where one was awaiting him or her without waiting for him or her without knowing what or whom top expect, what or whom I am waiting for - and such is hospitality itself, hospitality towards the event.(Derrida, 1993, p. 33)

What can be speculated regarding Dostoevsky's act of waiting is that his act of waiting starts as a stay anticipating the spectre of Pavel. But what Dostoevsky encounters at the final point of his wait is the event of writing and in extension his anticipation of his possible readers. In the novel one can observe how Dostoevsky the writer is unconditionally responsible and hospitable. He is hospitable to the event of writing when he thinks "I have lost my place in my soul" (Coetzee, 1994, p. 249). The author function present in the textual fold continuously goes through the process of 
self-annihilation, to be hospitable to the world he observes and the world he creates, but the figure is essential for the gestation of the textual world which is created.

\section{Reference:}

Attridge, Derek. (2004). The Singularity of Literature. London: Routledge. Print.

--- (2004). J.M. Coetzee and the Ethics of Reading: Literature in the Event. Chicago: Chicago U P, 2004. Print.

Attwell, David. (1992). Doubling the Point: Essays and Interviews. Cambridge: Harvard University Press. Print.

Bakhtin, Mikhail. (1981). The Dialogic Imagination. Trans. C. Emerson. Austin: Texas UP. Print.

Barthes, Roland. (1982). "Author and Writer." 1960. A Roland Barthes Reader. Ed. Susan Sontag. London: Vintage. 185-193. Print.

--- (1989). "The Death of The Author." 1968.Modern Literary Theory: A Reader. Ed. Rice Philip and Patricia Waugh. London: Bloomsbury. 185-189. Print.

---(1975). The Pleasure of the Text. Trans. Richard Miller. New York: Hill and Wang, 1975. Print.

---(1984). Writing Degree Zero. Trans. A Lavers. London: NP, 1984. Print.

Bennet, Andrew. (2005). Author. London: Routledge. Print.

Cobley, Paul. (2001). Narrative. London: Routledge. Print.

Coetzee, J M. (1997). Boyhood. London: Vintage. Print.

--- (2003). Elizabeth Costello. London: Vintage. Print.

---(2006). Slow Man. London: Vintage. Print.

--- (1994). The Master of Petersburg. London: Vintage. Print.

--- (2002). Youth. London: Vintage. Print.

--- "He and His Man". Nobelprize.org. The official website of the Nobel prize. 26 March. 2018. https://www.nobelprize.org/nobel_prizes/literature/laureates/2003/coetzee-lecture-e.html.

Derrida, Jacques. (1993). Aporias: Dying- Awaiting (One Another at) the "Limits of Truth". Trans. Thomas Dutoit, Stanford: Stanford UP. Print.

Lyotard, Francois. (1984). The PostModern Condition. Trans. Bennington andMassumi. Minneapolis: University of Minnesota Press. Print.

Waugh, Patricia. (1984). Metafiction: The Theory and Practice of Self-Conscious Fiction. London: Routledge. Print.

Readings, Bill--- The Gift of Death. (2007). Trans. D Wills. Chicago: Chicago U P. Print.

Head, Dominic. (2009). The Cambridge Introduction to J.M. Coetzee. Cambridge: Cambridge U P. Print. Jameson, Fredric. "Metacommentary." PMLA 86. (1971).

Jenny, Laurent. (1982). Intertextuality. OUP.

Readings, Bill.(1981).Introducing Lyotard: Art and Politics. London: Routledge. Print. 
The Author is Dead, Long Live the Author! Postmodern Metanarrative and the Performance of the Author Function 